\title{
Water and Human Health
}

\author{
Nasim Karim
}

Water is an essential requirement of human body. It makes up about fifty to seventy five percent of the human body. We can live without food for many weeks but for water it is only days. Water is part and parcel of our body tissues such as fats, muscles, bones etc and is the basic component of fluids like blood, juices in the digestive tract, sweat and urine. It is required on daily basis as human body cannot store it. Water being lost from skin, lungs, feces and urine needs replenishment on daily basis. However the daily amount required depends upon the body size, food intake, rate of metabolism, environmental and weather conditions and life style of any individual. On an average daily loss of water in adults accounts for two and a half to three litres whereas in elderly it is two litres per day that necessarily needs replacement to maintain health. ${ }^{1}$

About 1.1 billion people in the world do not have access to safe drinking water and eighty percent of all illnesses in developing countries are due to drinking unsafe water that causes 2.2 million deaths every year. ${ }^{2}$ Sea water accounts for ninety seven percent of water on earth while fresh water is only three percent. About sixty nine percent of fresh water is present in the form of ice and thirty percent as ground water. Out of this only 0.25 percent fresh water is easily available to us as surface water that is in the lakes and rivers. ${ }^{3}$ Thus safe drinking water is mainly available from the ground water. It has dissolved in it many types of metals and several other substances which are useful for human body but in a specific limit. ${ }^{4}$

The detailed insight into the story of water is, it maintains the (a) integrity of each cell present in our body (b) moistening of mucus membranes in the oral cavity and respiratory tract (c) fluidity of blood that keeps it flowing in our blood vessels with provision of nutrition and oxygen supply (d) the elimination of metabolic end products that is the waste products (e) fluid and electrolyte balance (f) body temperature (g) smooth mobility of joints by lubricating them (h) functioning of bladder by flushing and clearing the bacteria (i) composition of fecal matter good enough to avoid constipation (j) beauty of individual by keeping the skin moisturized and making the skin texture healthy $(\mathrm{k})$ proper functioning of eye, spinal cord and amniotic fluid through its shock absorbing activity and property. ${ }^{1}$

Besides drinking water there are other sources also that

Nasim Karim
Professor and Head, Pharmacology Department
Bahria University Medical \& Dental College, Karachi.
Email: nasimkarim.bumdc@bahria.edu.pk
Received: 27-05-2019
Accepted: 20-06-2019

provide water to the body ${ }^{5}$ About twenty percent of body water requirement can be fulfilled from food that we eat even if it is dry and solid while ten percent body requirement is met by the water byproduct produced as a result of digestive process in the body. This is a total of thirty percent therefore the remaining seventy percent water requirement of body is to be completed by intake of fluids mainly the drinking water. The daily requirement of women is 2.7 liters equal to eleven and a half cups and that of men is 3.7 liters equal to fifteen and a half cups of fluids. Majority of this intake should be preferably in the form of drinking plain water. Less water intake is needed in case of sedentary life style, cold weather conditions, diet composed of high water content like vegetables and fruits conversely more water intake will be necessary in case of active physical activities, hot and humid climatic conditions and diet composed of low water content. ${ }^{6}$ Moreover people on a high-protein diet, high-fibre diet, pregnant or breastfeeding mothers, having vomiting or diarrhea, active physically, living in hot climate areas require higher fluid intake in comparison to others. However drinks that contain artificial sweeteners and other sugary fluids such as soft drinks, vitamin added drinks, mineral water added with flavours, energy drinks should be avoided for use as they load the individual with large amount of additional energy that is kilojoules with no essential nutrient at all, leading to excessive weight gain and hence predisposing them to many diseases. Mineral water or commercially produced mineral bottle water should be avoided as it contains salt that predisposes to retention of fluid. This leads to swelling, increase in body fluid volume with resultant increase in blood pressure. Drinking simple/ plain water is the best choice as it has zero calories, easily available and above all is inexpensive. ${ }^{7}$

Water intake can be improved by the tips provided by Center of Disease Control and Prevention. These are: (1) At work place always carry water in a bottle to have easy and ready access (2) If ice cold water is the choice then use freezer safe bottles for cold water provision throughout the day (3) Avoid using water with added artificial sweeteners or soft drinks as they affect our body weight. 20 ounce of sweetened soft drinks/ soda contains 240 calories for which a healthy alternate with no calories is simple plain water (4) Save expenses by choosing water instead of beverages whenever eating out at lunch or dinner (5) Improve the taste of drinking water by adding a wedge of lime/ lemon. It also increases the desire to drink more water. ${ }^{8}$

The qualities that make drinking water safe and best for health are: (1) It should have an alkaline $\mathrm{pH}$ between 7.0 and 9.5(2) It should contain alkaline minerals such as magnesium and calcium (3) It should have anti-oxidant 
properties so as to slow down the aging process in the body (4) It should have no contaminants or toxins such as synthetic chemicals, radioactive substances, toxic metals, bacteria, viruses etc (5) It should have all naturally occurring minerals (6) It should have good taste in order to drink sufficient quantity to avoid dehydration. ${ }^{9}$

The US Center for Disease Control has notified that "Except for boiling, few of the water treatment methods are $100 \%$ effective in removing all pathogens." "Boiling can be used as a pathogen reduction method that should kill all pathogens. Water should be brought to a rolling boil for 1 minute. At altitudes greater than 6,562 feet (greater than 2000 meters), you should boil water for 3 minutes." "Water temperatures at $160^{\circ} \mathrm{F}\left(70^{\circ} \mathrm{C}\right)$ kill all pathogens within 30 minutes. Water temperatures above $185^{\circ} \mathrm{F}\left(85^{\circ} \mathrm{C}\right)$ kill all pathogens within a few minutes. In the time it takes for water to reach the boiling point $\left(212^{\circ} \mathrm{F}\right.$ or $\left.100^{\circ} \mathrm{C}\right)$ all pathogens will be killed, even at high altitude. The moment your drinking water reaches a rolling boil, the water has already become safe to drink."

In third world countries like Pakistan awareness regarding the importance of water for maintenance of health and use of safe drinking water must be disseminated to people by electronic and print media in the communities and at the level of schools, colleges and higher educational institutes with emphasis to use water only after boiling for a healthy living.

\section{REFERENCES:}

1. Water - a vital nutrient. Better Health Channel.VIC.GOV.AU. Last updated 2014. Accessed on $20^{\text {th }}$ June 2019.

2. SDWF- Safe Drinking water foundation. Water and Human Health.Water and human health fact sheet. Accessed on $20^{\text {th }}$ June 2019.

3. Lakshman N, Simanchal D, Durga P. Behera Drinking Water Characteristics Of Berhampur City, Orissa, India. Poll Res.2012: 31 (3) : 367-71.

4. Agrawal R. Physico-chemical Characteristics of Groundwater Quality of Gangapurcity Town in Rajastan. Poll. Res. 2010. 29(4): 683-93.

5. Sterns RH. , The treatment of hyponatremia. 2009 May;29(3):282-99. doi: 10.1016/j.semnephrol.2009.03.002.

6. . . Mayo Clinic .last updated September 6, 2017. Accessed on $20^{\text {th }}$ June 2019.

7. Which drinks are the best choice?- Dietitians Association of Australia-DAAhttps://daa.asn.au/smart- eating-for-you/smart.../ which-drinks-are-the-best-choice. Accessed on $21^{\text {st }}$ June 2019.

8. Water and Nutrition. Center for Disease Control and Prevention. CDC 24/7: Saving Lives, Protecting people. ${ }^{\text {TM }}$ Accessed on $21^{\text {st }}$ June2019.

9. Living Water. What Qualities Make for the Best Drinking Water?, . June 20th, 2017. Accessed on $20^{\text {th }}$ June 2019.

10. Bryan H. How Long to Boil Drinking Water? | GringosAbroad. Updated Mar 8, 2019. Accessed on $21^{\text {st June } 2019 .}$ https://gringosabroad.com/boil-drinking-water 